\title{
Reason Reconstituted: The Divine Attributes and the Question of Contradiction between Reason and Revelation
}

\author{
Rational Inference and the Question of Qiyās al-ghä’ib 'alā \\ al-shāhid
}

In chapter 5 , we discussed Ibn Taymiyya's charge against the philosophers that their reasoning about the world and metaphysical realities rests upon a fundamentally unsound ontology that confuses, on numerous levels, the realm of external ontological existence with the realm of notional or logical existence in the mind. Specifically, we have seen that the philosophers adopt a realist conception of universals on the basis of which they accord objective ontological status to notional realities (such as universals) that, Ibn Taymiyya insists, enjoy no more than intramental existence. As such intellectual realities are, by definition, unseen (ghayr mashhūd) and imperceptible (ghayr mahsūs), the philosophers identify them with the ghayb spoken of in revelation, in contrast to the shähid realm of our ambient empirical reality. The result is a philosophical ontology that confines the perceptible (mahsūs) to the empirical (shahāda) while reducing the unseen $(g h a y b)$ to the mental or intellectual (ma'qū $l)$. Such a scheme entails - incoherently, for Ibn Taymiyya - the affirmation of externally existent realities that are entirely notional and unperceivable (such as universals). Worse, insofar as the ghayb is reduced to the ma'qūl, the philosophers' schema at the same time necessarily precludes the existence of any independent, self-standing entities ( $a^{\prime} y \bar{a} n$ qã ima bi-anfusihāa) in the ghayb, entities that are inherently perceptible (though veiled to our senses at the current time) and that exist independently of human reason and human minds. It is on the basis of this ontology that the philosophers end up "intellectualizing" the various unseen $(g h \bar{a} i b)$ realities affirmed in revelation, as in their identification of angels with the "intellects" of the Aristotelian and Neoplatonic traditions or the broader philosophical view that the events of the afterlife, including the pleasures of paradise and the pains of hell, are merely graphic metaphors for what will essentially be experienced in intellectual, rather than sensory, terms in the hereafter.

This confusion in ontology, according to Ibn Taymiyya, has led to a parallel confusion in the rational inferences the philosophers draw about the world. 
Such inferences may collectively be referred to as qiyās, a term that, for Ibn Taymiyya, comprises both the categorical syllogism (qiyās al-shumū $\left.l^{1}\right)$, which operates on the basis of a universal middle term, and analogy (qiyās al-tamthïl), which involves the assimilation of two particulars by virtue of a relevant shared attribute without the mediation of a common universal. ${ }^{2}$ In both cases, an inference is drawn by transferring a judgement $(\mathrm{hukm})$, either from the universal to the particular (in the case of the categorical syllogism) or from the particular to the particular (in the case of analogy). ${ }^{3}$ The particular kind of inference relevant to the question of the divine attributes-and to the ghayb more generally_is known as "qiyās al-ghā'ib 'alā al-shähid," that is, "inferring [something about] the unseen on the basis of the seen," or, to put it in other terms, transferring a judgement applicable in the realm of the shähid to the realm of the $g h \bar{a} i b$. Ibn Taymiyya identifies four different kinds of inference, or

1 A term that may have been coined by Ibn Taymiyya himself. Hallaq, Greek Logicians, xiv, n. 17 .

2 The classic example of the categorical syllogism is "All men are mortal. Socrates is a man. Therefore, Socrates is mortal." The judgement $(\mathrm{hukm})$ of mortality is predicated of Socrates since he is subsumed by the middle term "man" and thus falls under the universal proposition "All men are mortal." A classic example of analogical reasoning, cited in Muslim juridical texts, is the following: "Grape wine (khamr) is forbidden because it intoxicates. Date wine (nabidh) also intoxicates. Therefore, date wine is forbidden too." Here the judgement $(\mathrm{hukm})$ of impermissibility is transferred from one particular (grape wine) to another particular (date wine) because they share a common relevant attribute, known as the illa, or ratio legis (in this case, intoxication). For Ibn Taymiyya's criticism of the syllogism, see Hallaq, Greek Logicians, xxvii-xxxii, as well as Rayan, "Ibn Taymiyya's Criticism of the Syllogism" and Rayan, "Criticism of Ibn Taymiyyah on the Aristotelian Logical Proposition."

3 Ibn Taymiyya, in fact, argues that these two forms of inference are equivalent in substance and that they differ only in form. The analogical syllogism, for instance, can easily be recast as a categorical syllogism if the relevant attribute (that is, the illa) has been correctly identified. Using our example of grape wine, date wine, and the attribute of intoxication (see previous note), we can say: "All intoxicants are forbidden. Grape wine (or date wine) is an intoxicant. Therefore, grape wine (or date wine) is forbidden." For Ibn Taymiyya's discussion of the substantive equivalence of analogy and the categorical syllogism, see Dar', 7:317-327 (esp. 7:318 and 7:322 ff.), as well as Radd, 115-122. See, in addition, Radd, 200-201, "talāzum qiyās al-shumūl wa-qiyās al-tamthīl wa-bayānuhu bi-l-amthila"; Radd, 201-203, "al-istiqrā’ laysa istidlālan bi-juz'ī 'alā kullī," where he explicitly denies that induction consists in inferring a universal on the basis of particulars; Radd, 208-214 and 233-238, responding to the critiques of the analogical syllogism put forth by Muslim rationalists; Radd, 348-351, "al-kalām 'alā jins al-qiyās wa-l-dalīl muțlaqan"; and, especially, Radd, 364-384, "al-adilla al-qāțía 'alā istiwāà qiyās al-shumūl wa-l-tamthīl." For a presentation of Ibn Taymiyya's views on the subject, primarily as expressed in his treatise Jahd al-qarīha, see Hallaq, Greek Logicians, xxvii-xxxix. A brief discussion can also be found in Heer, "Ibn Taymiyah's Empiricism." Heer points out that Ibn Taymiyya was not the first to argue for the equivalence of syllogism and analogy and that he was preceded in this by both al-Fārābī and al-Ghazālī. See, e.g., al-Fārābī, "Kitāb al-Qiyās," $36 \mathrm{ff}$. and 54ff.; al-Ghazālī, Míyār al-ilm, 165-166 ff. 
transfer of judgement, that one might make about the unseen realm on the basis of the perceptible realm. These inferences concern (1) factual existence (thubüt), (2) essential ontological reality (haqiqa) or modality (kayfryya), (3) meanings and notions (ma'āni ), and (4) logical principles and the fundamental axioms of reason (badihhiyyāt). Ibn Taymiyya contends that making an analogy from the seen $(s h \bar{a} h i d)$ to the unseen $(g h \bar{a} \vec{i} b)$ is illegitimate in the first two cases but mandatory in the second two. How is this so?

Ibn Taymiyya maintains that it is invalid to draw an analogical inference (qiya $\bar{a})$ or to transfer a judgement $(h u k m)$ from the seen to the unseen in terms of either the factual existence (thubüt) or the essential ontological reality (haqiqa) of something in the unseen realm. This is so because existence and ontological reality are both existential categories, and reason (as we know from chapter 5 ) cannot be used to establish the existence ${ }^{4}$ or the ontological reality of anything in the ghayb. ${ }^{5}$ In order to establish what exists in external reality, we are dependent on sensation (hiss) and transmitted reports (khabar). For our knowledge of the essential reality (haqīqa) of a thing, we are essentially dependent on sensation alone since, according to Ibn Taymiyya, it is only through direct empirical experience that we can gain any sense of a thing's ontological reality or its modality of being in the world. To put it another way, we can only know what exists through sensation or reports, while we can only know something about the essential reality of how a thing exists through sensation alone. This being the case, we cannot, on the basis of reason, affirm the factual existence (thubüt) of something in the ghayb based on what exists in the shahäda. We can only make such an affirmation if we have come to know of the thing's existence through one of the two sources of existential knowledge, sensation or transmitted reports. Likewise, once we know of the existence of something in the unseen realm, it is not legitimate for us, on the basis of reason, to assume a common essential reality (haqiqa) or equivalent modality of being (kayfiyya) between this and what exists in the perceptible realm. When Ibn Taymiyya states that the analogical inference from the seen to the unseen (qiyās al-ghäib 'alā al-shāhid) is "one of the most corrupt forms of analogy" ( min afsad al-qiyās) owing to the "(essential) difference in the ontological realities [of things]" (li-ikhtilāfal-haqā̄iq), ${ }^{6}$ it is qiyās primarily in this second sense (the sense of transferring a judgement concerning the essential ontological reality, or haqiqqa) that he has in mind. In short, since factual existence (thubüt)

4 See Dar', 5:254, lines 5-6, where he says, "lā siyyamā wa-l-umūr al-ghä’iba laysa lil-mukhbarīna bihā khibra yumkinuhum an ya lamū bi-'uqūlihim thubūt mā akhbara [Allāh wa-rasūluhu] bihi."

5 With the exception, once again, of God (as discussed previously).

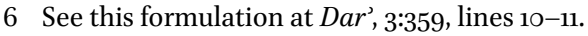


and essential reality (haqiqa) cannot be established by reason but can only be known through sensation or reports, reason cannot serve as a basis to transfer any judgement concerning either of these two things (factual existence or essential reality) from the seen to the unseen realm. Existence and essential reality in the unseen realm can only be established by the same means used to establish them in the visible realm, namely, sensation or transmitted reports for establishing factual existence (thubüt) and sensation alone for establishing essential reality (haqīqa) or modality (kayfryya). Reason, for its part, can serve neither to establish existence nor to make any judgement on essential reality or modality in the absence of either reports or direct empirical experience.

Now, where we can, and indeed must, make an analogy from the visible to the invisible realm is in terms of the second two categories mentioned above, namely, the transference of meanings and notions (ma'ān $\bar{l})$ and the application of fundamental logical and relational principles. What, for Ibn Taymiyya, is the precise nature of the correspondence between the seen and the unseen realms on the plane of meanings and notions? We recall that universal notions existing in the mind are a mere representation, or snapshot, of the external empirical realities mediated to the mind through the senses. Just as a camera can capture only what is in front of it, so too are the universal notions that the mind abstracts from particulars conditioned and determined by the existential reality of whatever they are abstractions of. Nevertheless, we can have some notional appreciation for entities in the unseen that are reported to us through khabar thanks to the names $(a s m \bar{a})$ by which these entities are described to us, even if we have no direct empirical experience of them. This is so because names (or "nouns," asma $\bar{a}^{\prime}$ ) denote meanings (ma'ānī), which are, precisely, notional realities subsistent in the mind. Ibn Taymiyya, in fact, explicitly likens such ma'āni to universals insofar as both are originally abstracted from particulars and reside as notions in the mind, notions that are capable of subsuming, or of being applied to, any number of extant particulars. Now, since the understanding and processing of meanings (and other universal notions) is precisely what the mind is made to do, we are able to comprehend-both semantically and notionally-something of those entities that resemble, in some respects ( $\min$ ba'd al-wujüh), what we know experientially in our own empirical realm.

We may illustrate this point by way of an example. If, say, we are informed through revelation that angels (existing in the realm of the ghayb) can see and we also know what it means for us in the realm of the shahäda to see-namely, to have visual apprehension of an object - then this shared meaning, which is based on a type of analogical signification (ishtiräkma'nawi ), must be applied to both the seen and the unseen realms equally. Thus, if angels see, this can 
only mean that they, like us, possess visual cognizance of objects since this is what the word "to see" means. Were this meaning not intended to apply to the angels when predicated of them, then revelation would simply not have used this term in speaking of them. In other words, there is a meaningful semblance of similarity (mushäbaha, tashābuh) between what seeing means in the case of angels in the ghayb and what it means in our case in the realm of the sha$h \bar{a} d a$. Were it not for this shared meaning (ma'na mushtarak), the statement "angels see" would have no appreciable meaning for us whatsoever and it would be nonsensical for revelation to have addressed us, concerning the angels, in these terms. It is noteworthy, however, that we have not established the very existence of the angels' sight on the basis of analogical inference (qiyās) or the transference of judgement $(\mathrm{hukm})$ from the seen to the unseen; rather, the existence (thubüt) of this reality is only known to us through transmitted reports (namely, divine revelation). Nor would we be justified in assuming any parallel in the essential ontological reality (haqiqa) or the precise modality (kayfiyya) of the angels' seeing since we have no empirical experience of the angels themselves, much less of the particular manner in which they see. Nevertheless, we can know what it means for angels to see, even if we cannot know exactly how it is that they do so. And, indeed, it is only by our transferring what it means to see - that is, the meaning, or mána $\bar{a}$, of seeing - from the visible to the invisible that we can understand anything reported to us about the unseen realm. Affirming a common meaning (ma'nā $)$ of shāhid and ghä ib entities while nevertheless admitting a substantive difference in the ontological reality (haqiqa) or modality (kayfiyya) in which this meaning applies to each entity is simply a rephrasing, in logical-rational terms, of our discussion in chapter 4. There, we distinguished the $t a^{\prime} w \bar{l} l$ of unseen entities that we can know (namely, $t a^{\top} w \bar{l} l$ in the sense of explication of meaning, or tafsir al-man'na) from the type of $t a^{\prime} w \bar{l} l$ that we cannot know (namely, $t a^{\prime} w \bar{l} l$ in the sense either of modality or of the ultimate reality or outcome of an affair [haqīqat mā ya'ülu ilayhi al-amr]]. ${ }^{7}$ In order to underscore the ultimate dissimilarity in essential ontological reality between the empirical and the invisible realms despite the applicability of common names to both realms and the comprehensibility of the universal meanings carried by these names, Ibn Taymiyya cites a saying of Ibn 'Abbās to the effect that "the only commonality between what exists in this world and what exists in paradise is the names [by which each is described]."

7 See chapter 4, p. 184 ff. above.

8 “laysa fì al-dunyā mimmā fì al-janna illā al-asmā’." Dar’, 6:124, line 3. (See Dar’, 6:124, n. 1 for the sources of this statement.) 
Yet some of what exists in the universe does not fit into our conceptual framework at all because, to use Ibn Taymiyya's term, it has no counterpart (nazīr) in our empirical realm whatsoever. Where unseen realities bear no meaningful resemblance whatsoever to any element of our experience, they cannot be meaningfully named since there are no notions (ma'ānī ) or universals abstracted from our realm that could meaningfully apply to them. This is why, in addition to all the pleasures of paradise, there exists, greater than all the rest, "that which no eye has seen, nor ear has heard, nor has occurred to the heart of any man." Notably, we find in this statement not only the denial of analogous empirical experience (no eye has seen and no ear has heard the likes of it) but the denial of any notional resemblance as well. Our minds, of course, can conceive of (yatașawwar) many things that do not, and even cannot, exist in the empirical realm, yet we still have the ability to imagine them; that is, they can exist as notions in our minds. But that which is reserved for the inhabitants of paradise has neither any empirical nor any notional resemblance to anything we know: it surpasses even our (relatively expansive) powers of imagination. Similarly, the soul (rüh) is not named or described any further; it is simply described as being "of the affair of my Lord" (Q.al-Isrä'17:85), a statement that underlines its unique nature and essential dissimilarity to anything else we know. Finally, while many of the attributes of God of which we have been informed correspond to attributes of which we have some experience (e.g., mercy, anger, kindness, majesty), the quintessential nature (kunh) of God cannot be known to us at all, not even by way of correspondence, similarity, or approximation. The complete and utter uniqueness and incomparability of the divine essence is, presumably, why the Prophet is reported to have instructed his followers not to ponder on God Himself but rather to ponder on His creation. ${ }^{10}$ Attempting to fathom God's ultimate essence is, in fact, pointless, as

"mā lā 'aynun ra’at wa-lā udhunun sami'at wa-lā khațara 'alā qalbi bashar" (Dar', 5:73, lines 14-15) — part of a hadīth qudsī, reported in, e.g., al-Bukhārī, Șaḥịh, 120o; Muslim, Sahịh, 1298.

10 "tafakkarū fì khalq Allāh wa-lā tafakkarū fì dhāt Allāh" (Ponder on the creation of God, but ponder not on God's essence) (Dar', 6:203, lines 9, 14)—reported as a saying of Ibn 'Abbās with a good chain of transmission (mawqū 'alā Ibn 'Abbās bi-isnād jayyid). See, inter alia, al-Bayhaqī, Kitāb Asmā' Allāh wa-șifātihi, 618, 887; Abū al-Shaykh al-Așbahānī, Kitāb al-'Azama, 1:212; Ibn Abī Shayba, al-'Arsh wa-mā ruwiya fìhi, 342-344; al-Dhahabī, Kitāb al-'Arsh, 2:133-134; Ibn Hajar, Fath al-Bārī, 13:383. Another report of this incident relates that the Prophet saw a group of people and asked them, "What are you doing?" They replied, "We are pondering on the Creator" (natafakkaru fi al-Khāliq). He said to them, "Ponder over His creation but ponder not on the Creator, [for] you cannot encompass His immensity" (tafakkarū fì khalqihiwa-lā tafakkarū fì al-Khāliq lā tuqaddirūna qadrahu). This report was narrated through Ibn 'Abbās and, with a stronger chain, as a mursal hadìth 
we can have no understanding of it whatsoever for the simple reason that it is totally unlike - in every respect ( $\left.\min j a m \bar{\iota}^{\top} a l-w u j u ̄ h\right)$ — anything of which we have any experience and, therefore, totally unlike anything of which we have any knowledge. ${ }^{11}$

The second type of analogy between the seen and the unseen that Ibn Taymiyya declares not simply legitimate but indeed mandatory is the analogical application to both realms of the basic rules of logic and the innate axioms of reason - what he refers to as the badihiyya $\bar{a}$. Such principles, being axiomatic and a priori (as established in chapter 5 ), neither derive from nor are dependent on empirical experience and, partly for this reason, are not confined to the realm of empirical reality. By their nature, logical principles hold true universally and without exception. Thus, if it is true in our empirical realm that a thing cannot simultaneously be and not be (an instance of the law of noncontradiction), then the same must be true in the unseen realm as well. In fact, our knowledge that this law holds true in our empirical realm is not based on anything we have observed in that realm. Indeed, it is difficult to imagine what it could even mean for us to have "observed" that something cannot both be and not be at the same time. Rather, we simply know, as a matter of logical necessity, that "to be" and "not to be" are mutually contradictory and logically exclusive opposites and that, by definition, they cannot hold true for any given entity at one and the same time. Being a question of (necessary) logic rather than (contingent) ontology, this and similar principles hold true-in fact, must hold true-by self-evident logical necessity in all possible worlds, including, naturally, the world of the unseen. We are therefore perfectly justified in applying such axioms to both realms of existence since, again, we are dealing with logical and relational phenomena and passing judgements on their basis- this being part and parcel of the rational faculty and, to a substantial degree, constitutive of its very essence. It is important to underscore the fact that logical axioms are applicable to both the seen and the unseen realms, for Ibn Taymiyya often attempts to reduce his opponents' theological positions to absurdity (positions that, ultimately, relate to something in the unseen realm, namely, God) on account of their violating one or another of these fundamental and universally applicable rules of thought. ${ }^{12}$

(that is, one in which the name of the Companion[s] who initially transmitted the report is not mentioned). See, e.g., Ibn al-Faḍl, Kitāb al-Targhīb wa-l-tarhīb, 1:39o (\#672); Hannād b. al-Sarī, Kitāb al-Zuhd, 469 (\#945).

11 See, e.g., Dar', 5:73, lines 7-16.

12 Such as the notion, examined in chapter 5 , that one could coherently maintain that God is neither one with the universe nor separate from it, neither inheres in the universe nor transcends it. See pp. 268-269ff. above. 
Now, Ibn Taymiyya accuses the philosophers of speculating about the unseen realm on the basis of the visible world in the first two domains discussed above, namely, factual existence (thubūt) and essential ontological reality (haqiq a). Yet the inference from the seen to the unseen, as we have learned, is illegitimate in these domains since we cannot independently establish the factual existence or the existential modality of any entity merely on the basis of reason. It is precisely because the philosophers, in Ibn Taymiyya's view, have treated unseen entities as essentially analogous to those in the visible realm, particularly in terms of essential reality (haqiqa), that they then feel compelled to deny what transmitted reports (khabar) - specifically those reports that constitute revelation in the form of the Qurān and hadīth-affirm of unseen realities such as the divine attributes so as to avoid the risk of likening God in essence (that is, in His haqiqa) to created things, which would be tantamount to tashbih, or assimilationism. But the philosophers' belief that affirmation of the divine attributes would entail such assimilation is a direct result of their false assumption that the unseen realm (ghayb) is comparable to that of the seen $($ shahäda). In other words, it is a result of the philosophers' false starting assumptions that they believe it possible to draw an analogy in terms of essence, modality, and ontological reality between the seen and the unseen realms. In this manner, they disavow the legitimate and required forms of analogy from seen to unseen-namely, the analogy that is necessarily involved in the affirmation of a common meaning $\left(m a^{\prime} n \bar{a}\right)$ and the common application of universal logical principles-because of the implications they believe are entailed by the illegitimate forms of analogy, those in which they have engaged on the mistaken assumption that there exists an essential ontological similarity between entities in the seen and the unseen realms that bear a common name.

In summary, the type of analogical inference (qiy $\bar{a} s)$ from the empirically accessible, "seen" realm (shahāda) to the unseen realm (ghayb) that Ibn Taymiyya holds to be both valid and necessary is a semantic and notional analogy on the basis of shared meanings, not an analogy related to factual existence $($ thubüt $)$ or essential ontological reality (haqiqqa). Though we cannot, on the basis of reason, deduce or infer the existence of anything in the unseen realm (other than God), we can nevertheless draw upon the universal meanings (ma'āni $)$ and notions (also ma'āni $)$ that reason has abstracted from the visible realm-meanings and notions in terms of which our very language is patterned, since it is through language that we name various existing objects-in order to understand something about entities in the unseen realm on account of these shared meanings (ma'äni mushtaraka). Nevertheless, we must recognize that the ontological reality, or haqiqa, of each entity is specific to the entity in question, and in that sense, entities in the realm of the unseen are essentially 
dissimilar to those in the visible world - that is, dissimilar in essence, which, for Ibn Taymiyya, is equivalent to a thing's very ontological reality. Finally, from a rational perspective, we must treat all realms of existence analogously with respect to the fundamental rules of logic. As a consequence, we must apply logical principles consistently both to the empirically accessible world around us and to the world of the unseen that lies beyond our sensory perception.

\section{Ibn Taymiyya's Reforms Applied:The Question of the Divine} Attributes

We have seen over the course of this study that the philosophers, in essence, make an appeal to reason ( $\mathrm{C} a q l)$ to argue that we must interpret the divine attributes figuratively (via $t a^{2} w \bar{l} l$ ) since affirming them would, on their view, entail that God and creatures participate ontologically in a common universal, negating God's unique and total dissimilarity to created beings and opening the door to tashbih (assimilationism). Ibn Taymiyya, for his part, insists that we are able to understand God's attributes by virtue of their subsumption, alongside attributes present in our world, under a common meaning or notion $\left(m a^{\prime} n \bar{a}\right)$. This, however, leads to a question. When Ibn Taymiyya says that we can only understand something if it possesses some resemblance to the created entities with which we are familiar, he explicitly uses the terms mushäbaha and mumäthala, cognates of tashbīh and mithl (as in Q. al-Shürā 42:11: "laysa ka-mithlihi shay"), respectively. How, then, does Ibn Taymiyya understand mushäbaha and mumāthala here in a manner that does not violate the import of this verse? In answer to this question, he maintains that there is no escaping (lä budda min) some element of commonality (qadr mushtarak) between any two existing entities, so we ought to be forthright in admitting this. Denying this premise directly entails a denial of God's very existence since one could easily argue that if God is said to exist and we are said to exist, then this would entail tashbih because the word "existence" is being applied equally to God and to us (al-ishtirākfi ism al-wujūd). This is precisely why the Bātiniyya, according to Ibn Taymiyya's understanding (as we saw in chapter 3), did not affirm God's existence, nor, absurdly, did they affirm His non-existence (thus violating the law of the excluded middle). By contrast, some later Sufis reached the opposite conclusion, maintaining instead that we do not exist-yet another absurdity for Ibn Taymiyya, of the order he routinely dismisses as "known to be false according to the necessary or self-evident principles of reason" (ma'üm al-fasād bi-darürat al-'aql or bi-l-badīha) and as "obstinately denying [what is obvious to] the senses and reason" (mukäbara lil-hiss wa-l-aql). 
But if there must be some element of commonality among all things that exist, including God and the created universe, where should we draw the line of acceptable overlap? At existence? At life, knowledge, and power? At mercy and retribution? Being separate from and above the universe? Possessing a hand? Ibn Taymiyya's answer to this question goes back to his conception of what we have been referring to as a thing's "essential ontological reality," or haqiqa. This essential nature, for Ibn Taymiyya, can be reduced ultimately to the question of a thing's fundamental ontological status, and specifically to whether its being, or its existence, is necessary, eternal, perfect, and indestructible, on the one hand, or contingent, temporal, deficient, and subject to ultimate destruction, on the other. It goes without saying that the first set of qualities belongs to God alone (qualities that, in fact, constitute the principle elements by virtue of which He is God), while the second set of attributes applies to all entities other than God, whether they exist in the visible world or in the realm of the unseen. It is these four fundamental qualities (necessity vs. contingency, eternality vs. temporality, perfection vs. deficiency, and indestructibility vs. destructibility) that, for Ibn Taymiyya, define the haqïqa, or fundamental essence, of any existing thing. Since this fundamental essence is entirely inseparable (outside the mind) from a thing's attributes, it follows that whatever attributes an entity possesses apply to it in a manner commensurate with the entity's underlying ontological reality as determined by this limited set of crucial traits. Thinking about it another way, we may say that all other attributes of a thing are "colored," or conditioned, by the ontological status (haqiqa) of the essence in which they adhere, as determined by the four traits enumerated above.

We may illustrate Ibn Taymiyya's point by considering the attribute of knowledge. While "knowledge" means the same thing with respect to God and to humans, namely, cognition of a knowable, the knowledge predicated of human beings applies to them in a manner commensurate with their underlying essential reality, namely, contingency, temporality, deficiency, and destructibility. Like our very essence, the attribute of knowledge we possess is created, contingent, non-necessary, limited, imperfect, and ultimately abrogable altogetheras, for instance, through dementia or other memory loss and, eventually, in a definitive manner through the death of the knower himself. God's attribute of knowledge, by contrast, is fully commensurate with the essential reality of the (divine) essence in which it inheres. It is, therefore-like God Himselfnecessary, unlimited (that is, it encompasses all possible knowables), perfect, and indestructible. So, while knowing means the same thing with respect to us as it does with respect to God (cognizance of a knowable) and, therefore, there exists a notional sharing between His knowing and ours, there is nevertheless a fundamental ontological distinction between the true reality (haqiqa) 
of God's (necessary and perfect) knowing, on the one hand, and our (contingent, deficient, and limited) knowing, on the other. It is precisely here that the fundamental—and, for Ibn Taymiyya, decisive — distinction lies between any and all of the attributes of God and the attributes of created things. There is indeed "nothing like unto Him" since He alone, along with all His qualities, is necessary, eternal, perfect, and so on. It is in this crucial respect, and not in any other, that there is no similarity (mushābaha) or likeness (mumāthala) — that is, no ontologically relevant similarity or likeness-between God and anything else. Nevertheless, there is (and necessarily so) a type of resemblance between God and creation on the purely abstract level of universal meanings (ma'āni $)$, without which, once more, we would have no comprehension whatsoever of anything that is absent from our senses. In the case at hand, the resemblance arises from the fact that both types of entities in question are qualified by the attribute of knowledge. We recall from our discussion in chapter 4 that were it not for this shared meaning (ma'na mushtarak), the phrase "God is AllKnowing" would mean nothing to us at all. It would be the same, Ibn Taymiyya remarks, as saying that God is "kajz" or God is "dī" or other such nonsensical statements constructed of meaningless utterances (alfāz). Yet it is precisely because the very essence and reality of a thing coincides, for Ibn Taymiyya, with its concrete ontological existence and not with the notional reality of it as conceived in the mind that he is confident in affirming all the attributes predicated of God in revelation, without running the risk of falling into the relevant kind of tashbih (which is to say ontological, and not merely notional, tashbih). For Ibn Taymiyya, we make proper tanzih of God not by denying of Him any and all attributes that can also be truthfully predicated of a created entity. Rather, we do so in two distinct and very specific ways: (1) by affirming of His essence the four essential qualities mentioned above and negating of Him their opposites and (2) by affirming of Him only what Ibn Taymiyya calls "attributes of perfection" (sifät kamāl), such as life, power, and knowledge, and negating of Him their opposites (death, weakness, ignorance, and so forth). The first represents a tanzīh of God's essence; the second, a tanzīh of His attributes.

This way of looking at things allows God to be comprehensible to us - that is, we can understand who God is in our minds/hearts - without, however, His being "like" us or comparable to us in any ontologically relevant way, that is, in any way that would compromise His divinity by implying anything of the deficiency (naqs) or contingency by which we and every other created entity are characterized. We can understand who God is precisely because we are able to understand the meaning - and thus the ta'wil in the sense of tafsir al-ma'na (simple explication of the sense) —of the terms used to denote His attributes. Nonetheless, we can never fathom the true (ontological) reality - that is, the 
haqiqa - of these attributes nor, a fortiori, of His quintessential nature (kunh). This is true, as we have seen, because all existential knowledge is based on sense perception, and we only have sensory experience of a created and contingent empirical reality. We thus have no relevant experience in our empirical world on the basis of which to make an analogy (qiy ass) from it to the realm of the unseen. And if this is true even with respect to the created entities of the unseen realm, then it is, emphatically, even more true with respect to God, the necessarily existent Creator of all contingent being.

\section{3}

\section{Concluding Reflections}

The Dar' ta'ärud al-'aql wa-l-naql represents Ibn Taymiyya's attempt to transcend the centuries-old conflict between reason and revelation that had been raging on the Islamic intellectual scene from as early as the beginning of the second/eighth century. Though reason and revelation each make various kinds of affirmations that may potentially come into conflict, we have seen that the main focal point of this debate in medieval Islam centered on the question of the divine attributes. The Qurān and prophetic hadith ascribe to God a large number of discrete qualities, some or all of which are denied by various philosophical and theological schools of thought or interpreted in a metaphorical fashion (via $\left.t a^{3} w \bar{l} l\right)$ on the basis of rational objections to the alleged implications of a straightforward, "literal" affirmation of the qualities in question. Affirmation of the offending attributes is often believed to entail an unacceptable assimilation of God to created beings (tashbìh) or otherwise to infringe upon philosophical notions of an utterly simple divinity uncompromised by the "compositeness" allegedly entailed by the possession of particularizing qualifications.

Ibn Taymiyya rejects in principle the type of rationalistic $t a^{3} w \bar{l} l$ employed by the philosophers, the Mu'tazila, and the later Ash'ari theologians on the grounds that it does violence to the language of revelation and, no less significantly, is diametrically opposed to the radical affirmationism that he insists was the universal stance of the Salaf and early authorities. Beyond this, he instinctively rejects the purely abstract notion of God entertained by the philosophers, for two main reasons: one ontological, the other moral and religious. Ontologically, as we have seen, Ibn Taymiyya insists that abstract notions can only exist in the mind, with the result that the more God is conceived as being abstract and wholly undefinable, the more He is reduced from the status of an objectively existent personal God to that of an amorphous mental construct existing solely in the mind of the philosopher. To Ibn Taymiyya's mind, the philosophers' 
God simply does not and cannot exist in external reality-a fact that explains his charge that they were de facto atheists, ${ }^{13}$ however lofty and laudable their intentions may have been in attempting to safeguard our conception of God from anthropomorphism and other unbecoming forms of assimilationism. In addition to his ontological concerns, the moral and religious implications of such an abstracted and ethereal view of God were naturally not lost on Ibn Taymiyya either, and, in fact, they stand at the center of his motivations for attempting to refute philosophically inspired "negationism" once and for all. Indeed, one cannot very well pray to a God incapable of hearing one's prayer, nor yet draw close to a God who is unaware of one's particular existence. The loss of God's intelligibility to us that is implicit in the philosophers' radically negative theology undermines our ability to relate to God in any meaningfully personal manner and, therefore, thwarts what Ibn Taymiyya holds to be the very purpose and pith of religion: namely, to know God (which requires that He be reasonably intelligible to us), then, consequently, to love and to worship Him. As man's ultimate felicity is dependent precisely on his doing these three things, any intellectual construct apt to foreclose his ability to do so must needs be seen as a barrier to the achievement of that very felicity of the human soul that both philosopher and theologian ultimately seek.

Yet in his affray against the philosophers, Ibn Taymiyya is not content simply to assert the preeminence of revelation over reason, bidding reason to dutiful silence wherever revelation has spoken. Rather, he endeavors in the Dar' not merely to refute the individual arguments of the philosophers and theologians but also to demolish the very foundations-linguistic, ontological, and epistemological—on which their "negationism" is based. True to his empiricist methodology, Ibn Taymiyya starts from the consideration of one particular issue, that of the divine attributes. Yet in the process of attacking and deconstructing an enormous array of arguments over the course of 4,046 pages of printed text, he implicitly constructs an alternative system of knowledge based on a reformed approach to language, a reconstructed ontology, and a broadly reconstituted notion of reason. Ibn Taymiyya secures a firm place in his new epistemology for true reports (khabar șādiq) — particularly in the form of authentic revelation (naql sahịh) — as a major source of objective knowledge

13 Ibn Taymiyya often refers to the philosophers as malăhida, a term that is closer, in classical usage, to "heterodox" or "heretical" than to outright "atheist" as implied by the term as it is used today. However, he often charges them with tațill, that is, the comprehensive denial, or "nullification," of God's attributes, which, he maintains, is equivalent to the negation of God Himself. In Ibn Taymiyya's writings, we also encounter the terms mu'ațtila and mu'atțilat al-Șāni', sometimes in reference to the philosophers as a whole, but more often to the Bāținiyya as well as to the materialists (dahriyya), the Sumaniyya, and other such groups. 
about the world, in both its empirically accessible ("seen") and its unseen dimensions. While he relentlessly attacks the philosophers' realist ontology of universals, he nevertheless validates the abstracting and universalizing function of the mind and, in fact, makes this function the cornerstone of our notional access to the realm of unseen realities, including the attributes of God. Ibn Taymiyya's insistent differentiation between the existential category of essential ontological reality (haqiqa), on the one hand, and the notional categories of universal concepts (kulliyyāt) and meanings (ma'ānī), on the other, allows him to uphold the integrity and the intelligibility of the language used of God in revelation while simultaneously steering clear of tashbih, interpreted as the implication of any ontologically relevant similarity between the eternal, necessary, and perfect God and His temporal, contingent, and necessarily imperfect creatures. Ibn Taymiyya's insistence on the ontological indivisibility of essence and existence - and particularly of essence and attributesallows him to articulate a limited, ontologically relevant set of divine attributes (necessity, eternality, perfection, and indestructibility) that, above all else, are what radically distinguishes God's essential being from that of every other existing thing. Being of the essence, these qualities pervade the divine being and determine the ontological quality of all other attributes pertaining to God. In doing so, they exonerate the divine attributes of any deficiency one might erroneously attribute to them on account of the notional semblance they share with corresponding attributes found in human beings or other created entities. Ibn Taymiyya's insistence on the universal applicability of the a priori logical principles lodged in the mind allows him to dismiss out of hand a number of "negationist" theses on the grounds that they run afoul of the elementary principles of rational thought. Ultimately, Ibn Taymiyya grounds the final integrity of his system, and indeed of all human knowledge, in the cognitive-moral notion of the fitra, or original normative disposition, and in an expanded application of the principle of tawätur, against which all sources of knowledge and modes of cognition can ultimately be verified.

In broadening the sources of authentic knowledge, Ibn Taymiyya simultaneously widens the scope of the means and the steps by which knowledge can arise in the mind of a given individual. ${ }^{14}$ Though knowledge itself is perfectly objective, in the sense that it corresponds to (yutäbiq) what is factual and true in and of itself (mā huwa thäbit fi nafs al-amr), the discrete process by which one acquires knowledge of any given knowable (ma'tüm) is nevertheless personal, situational, specific, and individual. Typical of Ibn Taymiyya's thought, there are no universal rules or necessary order of steps

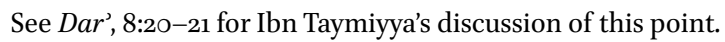


that apply to all cases. The various means of acquiring knowledge-sensation (hiss), true reports (khabarșādiq), the self-evident axioms of reason (badīhiyyāt al-'aql), sound inference (nazar hasan), various incarnations of the mechanism of tawātur, the possession of a sound cognitive-moral disposition ( fitra salima) - all stand objectively at every person's disposal, yet there are often numerous paths one can tread, various corroborative combinations of these elements through which a person can attain knowledge of a given reality. What ultimately counts is the result, namely, the occurrence of knowledge in the heart/mind (ḥusūl al-ilm fi al-qalb). Some knowledge is gained empirically, some through reports, some through rational inference, some by intuition, and, as in the case of tawatur, the amount and the kind of corroborative evidence necessary to bring about knowledge are not necessarily the same for each and every person. It is misleading and abusive to confine knowledge in general to a particular order (tartïb mu'ayyan), as do the philosophers, or to confine knowledge of God and the authenticity of revelation to a particular order, as do the theologians, or to confine the means of progress along the spiritual path (alwuṣu li ia Allāh) to a particular order, as do those who theorize Sufism; for, while there may be a set order in the mind when one theorizes about the acquisition of knowledge, the manner in which knowledge actually comes about in the external world ( $f \grave{i}$ al-khärij) is rarely, if ever, constrained by the theoretical order projected by the intellect. Indeed, Ibn Taymiyya remarks, the various ways of coming by knowledge, the conditions attendant thereupon, and the means $(a s b \bar{a} b)$ and order of the steps (tartīb) through which knowledge is attained are too diverse and expansive to be confined to only a few discrete pathways or methods. ${ }^{15}$

Though Ibn Taymiyya does not say so himself, this idea of variegated yet mutually corroborative paths to knowledge of a single fact or reality is reminiscent of the transmission of mutawätir hadīth reports, whereby different individuals may have one and the same hadith from a varied conglomeration of sources. Each is justified in claiming knowledge of the hadith's authenticity since he has received it from enough mutually corroborative sources to experience within himself assurance (țuma'nina) and firm conviction (itiqād jäzim) that the hadith is true. That is, each has justified and sufficient (though not necessarily identical) grounds to hold that knowledge of the hadith's authenticity has successfully "occurred in his heart/mind" (hașala fi qalbihi). As we have seen, the idea and method of tawātur run consistently throughout Ibn

15 "wa-țuruq al-'ilm wa-l-aḥwāl wa-asbāb dhālika wa-tartībuhu awsa' min an tuhșara fì ba'd hādhihi al-țarāiq." Dar', 8:21, lines 4-6. 
Taymiyya's epistemology, whereby he appeals to some notion of tawātur as the final justification even for knowledge that is essentially empirical, as well as for knowledge that is of an intuitive or a priori nature. Thus, as we reflect upon the underlying themes of Ibn Taymiyya's approach to knowledge, inferences, and proofs, it is not surprising to discover that he conceives of these in much the same way across all domains. Beyond its thoroughgoing consistency, Ibn Taymiyya's epistemology represents an attempt to profile the sundry ways in which knowledge is actually engendered in the real world. He presents this epistemology as an alternative - and, to his mind, an antidote- to the various methods and categories of the philosophers. In Ibn Taymiyya's view, not only is the way of the philosophers arbitrarily restrictive-with a heavy, almost exclusive reliance on formal, syllogistic demonstration — but it is also anathema to him insofar as he considers it to be based on a purely abstract and idealized notion of what constitutes proof or a reliable indicator of knowledge. ${ }^{16}$

Ibn Taymiyya's empirically grounded and widely cast epistemological framework underscores a larger commitment on his part to a broad-based, fundamentally catholic vision of human knowledge. ${ }^{17}$ Ibn Taymiyya censures the philosophers for presuming that theoretical or speculative reason holds pride of place in the epistemic hierarchy, sometimes to the point that they allow it to override more basic empirical or a priori knowledge, which, in turn, they demote to mere "estimation" (wahm) or "imagination" (takhyll) in order to accommodate the deliverances of abstract speculation. For Ibn Taymiyya, this state of affairs is entirely backward, for it is precisely the immediacy and sheer self-imposition of these basic sources of knowledge that justify them and ground their ultimate authority. This principle holds for Ibn Taymiyya's larger conception of "pure reason," or 'aql șarịh, as well. I have referred to Ibn Taymiyya's notion of reason primarily as "pure" or "true" or "sound" reason, but his specific use of the term șarịh—as opposed to a term like salim or șahịh —is not, I think, a mere play on words for the sake of euphony, as when the phrase "aql șarīḥ" is paired with "naql șahịh." Rather, his use of the term șarịh (clear, pure, unadulterated) is deliberate, for it is precisely șarịh reason that is șahịh reason: correct and valid. ${ }^{18}$ Sound reason and valid rational knowledge are

16 See Ibn Taymiyya, Radd, 88, "hașrr al-'ilm 'alā al-qiyās qawl bi-ghayr 'ilm." Also Radd, 122125, 162-163.

17 Yahya Michot has come to a similar conclusion. See, e.g., Michot, "Mamlūk Theologian's Commentary," 170-172. See also Hoover, Ibn Taymiyya's Theodicy, 22.

18 Consider the following phrase: "al-țuruq al-fitriyya al-'aqliyya al-shariyya al-qarïba alșahịha." Dar', 8:314, line 13. The various terms Ibn Taymiyya associates here- "innate" ( fitrī), "rational" ('aqlī), "scriptural" or "scripturally validated" (shar'̄), "commonplace, familiar" (qaīb), and "valid, correct" (șahịh)—are a keen indicator of his overall views 
guaranteed by the same immediacy and self-imposition as all other sources of knowledge-yet another instance of the consistency of Ibn Taymiyya's thought and methodology across various domains. This explains why arcane, circuitous, highly speculative — and, therefore, highly contentious and disputed-premises and arguments necessarily arouse Ibn Taymiyya's suspicion, as these epistemic vices are the polar opposite of those qualities that guarantee the integrity of our knowledge in all other domains. ${ }^{19}$ Why then, Ibn Taymiyya seems to be asking, should rational knowledge, to the exclusion of all other avenues of knowing, form a singular exception to the rule of immediacy and intuitive clarity? For Ibn Taymiyya, it is simply inconceivable that the propositions held instinctively to be true in a natural and unaffected manner by multitudes of average human beings could be subject to falsification on the basis of the recondite philosophical musings of the few, who even have trouble reaching agreement among themselves on the sundry conclusions of their speculative endeavors. Overriding the intuitions of the many in favor of the speculations of the few, he argues, would effectively destroy the possibility of any objective, publicly shared rational knowledge whatsoever.

The foregoing considerations highlight Ibn Taymiyya's acute sense of epistemological egalitarianism, at least concerning broad principles and basic inferences. In Ibn Taymiyya's epistemology, authentic knowledge is available to anyone whose basic rational faculty and fitra are intact, not just an elite coterie of philosophers who maintain an entirely different conception of reality from that of the common man. He does, of course, admit that particular sciences, be they religious or secular, are necessarily cultivated by specialists who, naturally, know better and know more about the subject at hand than the nonspecialist. This holds true in such domains as law, haditth, tafsìr, and grammar, but also in non-religious sciences like physics, astronomy, and medicine. Yet these individual sciences do not touch upon, nor purport to set the agenda for, a larger epistemological project aimed at defining what does and does not constitute ultimate truth and reality. In other words, they do not aim to underwrite an entire Weltanschauung, as do the core philosophical disciplines of metaphysics, ontology, and epistemology. It is inconceivable to Ibn Taymiyya that foundational matters of such comprehensive reach, which determine to a large extent a person's fundamental existential orientation, should be captive to the

regarding the character of truth and of the pure reason ('aql șarīh) by which it is ascertained, appropriated, and comprehended.

19 Recall from chapter 4 his citation of 'Abd Allāh b. Mas'ūd's characterization of the Salaf as "having the purest hearts, possessing the deepest knowledge, and exhibiting the least unnatural strain and affectation (takalluf)" of all Muslim generations. (See p. 208 above.) 
ruminations of a small group of conflicted specialists. The basic facts about reality, the universe, God, and man are truths available equally to anyone whose fitra and reasoning have not fallen prey to corruption. Ibn Taymiyya holds this position with respect to both rational and theological truths, for the Qurān is addressed to the commoner as well as to the elite. Furthermore, he insists, it conveys a unified and consistent doctrine that can be comprehended by all, and in essentially the same terms. As in other fields of knowledge, some may be more knowledgeable than others about the details of the specialized religious sciences, but there can be no fundamentally different mode of reading the texts reserved for the elite (as advocated, for example, by Ibn Rushd).

Once again, we can discern a parallelism here in the way Ibn Taymiyya treats rational knowledge and revealed knowledge, as both are integrated into an organic epistemology characterized by a high degree of consistency and correspondence among its various components. In the case of both religious and non-religious knowledge, the basic principles are self-evident and known to all, with details filled in by studied specialists. Yet the detailed knowledge of the specialist serves primarily to elaborate the already existing, publicly shared base of the knowledge in question; it does not, for Ibn Taymiyya, represent a situation in which the "true" knowledge possessed by the elite constitutes a fundamental departure from what is generally understood to be the case by the common man. Ibn Taymiyya's aversion to the convoluted nature of the philosophers' discourse and his disdain for what to him are their tortuous meanderings and abstruse doctrines should in no way be taken as an indication of a shallow wit on his part or an insufficient capacity truly to grasp and to come to terms with his opponents' contentions. Indeed, his ability to pen a work such as the Dar'ta'ärud establishes beyond any doubt that Ibn Taymiyya was no philosophical simpleton.

Of all the various elements of Ibn Taymiyya's reconstituted rationality, perhaps the most intriguing, original, and also the most subtle is his conception of the nature and function of the fitra. While it is impossible to do justice to our author's understanding of the fitra in a few short paragraphs, ${ }^{20}$ our exploration of reason and rationality in Ibn Taymiyya's thought would be incomplete were I not to offer, in closing, a few brief reflections on this central concept. We encountered the concept of the fitra in chapter 5 primarily as a cognitive faculty that overlaps to a considerable degree with the intuitive or a priori knowledge lodged in the mind ab initio. Beyond this, however, Ibn Taymiyya also suggests that the fitra is that faculty by which we judge both the soundness

20 For more extensive treatments of the fitra in Ibn Taymiyya, see sources listed at p. 26o, n. 113 above. 
of premises used in a demonstration and the soundness of the deductive arguments built upon such premises. ${ }^{21}$ Yet the fitra is more than this. I have suggested that an apt translation of the term fitra might be "original normative disposition," and indeed, Ibn Taymiyya's variegated appeals to the fitra in diverse contexts indicate that we should regard fitra as a more general, underlying principle that has relevance to and informs the various other faculties we possess - not only cognitive but moral-ethical and spiritual as well. In fact, from Ibn Taymiyya's perspective, it would be more accurate to say not that fitra is a moral and cognitive faculty but rather that it is a moral cum cognitive faculty, as ultimately the two cannot be definitively separated. Perhaps we can best understand Ibn Taymiyya's point by considering the following anecdote.

Ibn Taymiyya relates that Fakhr al-Dīn al-Rāzī and a certain Mu'tazilī theologian with whom he had been debating were one day visiting a Sufi shaykh in Transoxania who claimed to have achieved certain knowledge ('ilm al-yaqin). ${ }^{22}$ Al-Rāzì and his companion were surprised at the shaykh's claim since the two of them had been debating theology for years, constantly refuting each other's arguments but never able to break through to any indisputably certain conclusions on the topics of contention between them. When asked how he had achieved this certainty in knowledge, the shaykh responded, "[By] divine disclosures (or gifts in the form of insights) (wäridāt) that come over the soul and that the soul is unable to deny."23 Ibn Taymiyya reports that the Mu'tazili theologian, who had been complaining of doubts and confusions (shubuhāt) burning up his heart, took to the way of the shaykh and eventually reached the stage where God blessed him with similar gifts of divine insight, whereupon he declared that if upholding the apparent (zähir) sense of "The Most Merciful has settled upon the throne" 24 constitutes corporealism (tajsim), then, by God, he is a corporealist. Ibn Taymiyya reports that this (former) Mu'tazili, having returned to the way of affirmationism through the spiritual insights vouchsafed directly to his heart, went on to become one of the most illustrious (Sufi)

21 See, for example, Dar', 7:37, lines 17-19, where he states, "wa-illa fa-man raja'a fi muqad-

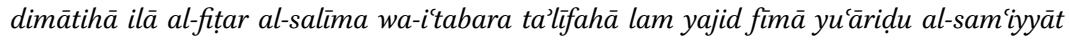
burhānan mu'allafan min muqaddimāt yaqīniyya ta'lifan șaḥịhan" (Whoever judges the premises [of an argument] and their manner of composition in light of his sound fitra will not find any [conclusion] that contradicts revelation to rest on a demonstrative proof validly constructed from definitively true premises). Here, Ibn Taymiyya explicitly states that we must return to "sound fitra" to judge the premises (muqaddimāt) of an argument, as well as the construction ( $\left.t a^{\prime} l i f\right)$ of the demonstration itself.

22 For this anecdote, see Dar', $^{\prime}$ 7:430, line 17 to 7:432, line 6.

23 "wāridāt taridu 'alā al-nufüs ta'jizu al-nufüs 'an raddihā." Dar', 7:431, lines 7-8.

24 “al-Raḥmānu 'alā l-'arsh istawā" (Q. Țā Hā 20:5). 
shaykhs of his day in the lands of Jurjan and Khwarizm. The point of this episode, and Ibn Taymiyya's approbatory citation of it, seems to be that certitude in knowledge is achieved when the heart/mind (qalb) has come to experience whatever knowledge it possesses as certain and entirely immune to doubt or recusal. As we saw above with respect to knowledge more generally, one is not necessarily obligated to follow a particular path to reach this certitude, nor does this certitude necessarily have to be articulable through particular expressions or modes of rational inference or analysis. In the case at hand, our theologian and his shaykh appear to have gained and experienced certitude directly from their fitra. ${ }^{25}$ If the fitra has been corrupted-through, for instance, the inculcation of erroneous doctrines that contravene necessary and intuitive knowledge, as was the case with the "negationism" of al-Rāzìs companionthen there are various ways in which this fitra can be resuscitated and returned to its original state. This might involve a process of sound rational investigation (that is, husn al-nazar and not the purely speculative argumentation of the philosophers and the mutakallimün), or spiritual purification (as in this case of our theologian with the burning heart), or other means. Ibn Taymiyya's point is that regardless of the means adopted, once the fitra has been rehabilitated to its natural, healthy state, it is often able simply to recognize the truth as such, in much the same way that the body possesses a capacity (quwwa) by which it instinctively distinguishes wholesome food from foul. ${ }^{26}$

The fact that the fitra is both a cognitive and a moral faculty introduces an important ethical and existential dimension into the process of knowing-a dimension that Ibn Taymiyya would argue is always present implicitly, albeit usually unacknowledged. This conception of the fitra provides for a richer and more nuanced account of knowledge and the process of coming to know. But does the introduction of an ethical and moral aspect into the cognitive functions of the fitra - and of the intellect more generally — render knowledge, for all intents and purposes, hopelessly subjective? After all, the primordial fitra with which each child is born ${ }^{27}$ is often corrupted, as we fail more often than not to maintain it in its original normative state. In practice, this original normative fitra is routinely reshaped — and, indeed, corrupted — by the ambient beliefs and practices of one's society. On this point, Ibn Taymiyya makes what,

25 Ibn Taymiyya certainly holds that the healthy fitra can recognize the truth of the affirmationists' position regarding the divine attributes.

26 Dar', 5:62, lines 11-15.

27 From the hadīth "Every child is born on [i.e., in a state of] the fitra" (kullu mawlüdyūladu 'ala al-fitra). See discussion at p. 26o ff. above. For documentation of the hadith itself, see p. 261, n. 117 . 
to my mind, is a remarkable observation regarding the relativity of what passes for "reason" in a given culture. He observes, almost in passing, that "every nation or society (umma) has what it calls 'rational knowledge' (ma'qülät)." ${ }^{28}$ In other words, he is telling us, a great deal of what is taken as rationality in any given time or place is ultimately determined by the dominant presuppositions and mental habits of a people that, by virtue of their near ubiquity, take on the appearance and force of necessary truths, simply given and utterly taken for granted. Ibn Taymiyya, without a doubt, views the philosophers as being precommitted (quite in spite of themselves) to an intellectual system characterized by a very particular (not to mention peculiar) view of reason and reality, a system that they have adopted, in essence, not as a matter of pure rationality and the unbiased cogitations of objective reason but, rather, as a matter of habituation to a transmitted doctrine and basing themselves, ultimately, on the mere "imitation" (taqlid) of their own earlier authorities - their own "Salaf," we might say. ${ }^{29}$ For Ibn Taymiyya, the philosophers' idiosyncratic views regarding the intelligible world, the various intellects, and so forth derive so clearly from the parochial ma'qūlät of one particular umma and lack any kind of objective proof or verifiability from either sense perception or transmitted reports (in the form of authentic revelation); yet the philosophers illegitimately universalize such "ma'qülāt" and confound them with reason per se. But longstanding acclimatization to essentially unfounded beliefs about the world derived through pure speculation can eventually pervert the cognitive dimension of the fitra. Add to this the moral corruptibility to which all are susceptible in some measure and the primordial fitra would seem to be hopelessly and irretrievably lost. Between culturally inflected notions of rationality and the capriciousness of our own selves, we would seem to be sunk in an intractable quagmire of parochialism and subjectivity.

Yet Ibn Taymiyya is no postmodernist. Objective truth, he insists, not only exists but is also ascertainable. In the previous chapter, we examined at length the various means at our disposal for acquiring knowledge about the worldin both its empirically accessible (shähid) and its "hidden" or unseen (ghäib)

28 "mā min umma illā wa-lahum mā yusammünahu ma'qūlāt" (emphasis mine). Dar', 5:243, lines $16-17$.

29 See Dar', 9:254, lines 16-17, where Ibn Taymiyya refers to Ibn Sīnā's famous Kitāb alIshārāt wa-l-tanbīhāt as "the Qurān/holy writ (mușhaf) of those philosophers" (also cited in Michot, "Ibn Taymiyya's Commentary on Avicenna's Ishärāt, namaț X," 12O-121). See similar at Dar', 6:19, lines 7-8, where he says that the Ishārāt is "like the Qur'ān to those heretical philosophizers/pseudo-philosophers" (hiya ka-l-muṣhaf li-hä’ulā̉i al-mutafalsifa al-mulhida) and Dar', 6:55, line 13, where he refers to namaț IX of the Ishārāt, "Maqāmāt al-ārifin," as "the epilogue (khātima) of their mușhaf [i.e., the Ishārāt]." 
dimensions - such as sensation, transmitted reports (particularly revelation), the apprehension of fundamental rational axioms, and sound inference. I have also described Ibn Taymiyya's understanding of the fitra as underlying-and thus informing and affecting the functioning of - these other sources. Fitra is to the moral-cognitive dimension of a man as health is to his body. Good health entails the proper functioning of all our various sensory organs, limbs, and other physiological systems. Ill health impairs them all alike. Indeed, Ibn Taymiyya defines true rational knowledge ('aqliyyāt) as that which is intelligible $\left(m a^{\prime} q \bar{u} l\right)$ and recognizable as such to the healthy fitra..$^{30}$ This being the case, he suggests that one way of resolving intractable disputes over knowledge and truth (such as those between al-Rāzī and his Mu'tazilī friend) is by seeking recourse to those of sound fitra (like the Sufi shaykh from Transoxania). But if the totality of our cognitive and moral faculties are dependent on the health of the fitra and if the fitra itself is not immune to dereliction, then wherein lies the ultimate grounding, and guarantee, of our faculties of reason and cognition?

The answer to this question brings us full circle. Ibn Taymiyya, we have remarked, views reason and revelation as mutually concomitant (mutalāzi$m \bar{a} n$ ), each ultimately entailing the other. Following reason, he insists, must eventually lead to the investigation and affirmation of the truth of revelation. Starting with revelation quickens reason, inciting us to reflection and exemplifying the optimal use of reason and rational inference. Yet this concomitance between reason and revelation involves a much deeper symbiosis. Revelation is addressed to intelligent beings and cannot be properly understood in the absence of pure reason ('aql șarih) and sound rational investigation (nazar hasan), as we have explored over the course of this study. More significantly, however, reason itself-particularly through its foundation in the moral-cognitive faculty of the fitra-cannot hope to function properly and to fulfill its own native potential without the guiding light of revelation and the ethical practice of religion to which revelation summons.

Here, at the end of our journey, we recall the very first page of the Dar' ta'ärud, where Ibn Taymiyya cites the universal rule and its contention that, should reason and revelation ever conflict, revelation must yield to reason since it is the latter that grounds our rational assent to the authenticity of the former. While it is true, for Ibn Taymiyya, that our knowledge of the authenticity of revelation is (or at least potentially is) grounded in reason, he is adamant that pure reason and authentic revelation-'aql șarịh and naql șahịh —can never conflict (as he argues most insistently in the Dar' with respect to the sud idrākuhā." Dar', 7:43, lines 3-4. 
divine attributes). Yet beyond this mutual implication and harmonious concordance, if it is true that reason, to a degree and from a certain perspective, undergirds our knowledge of the authenticity of revelation, it is nevertheless revelation that, in a deeper and more all-embracing manner-precisely through maintaining the moral and cognitive viability of the fitra-ultimately grounds, preserves, and promotes the proper offices of reason. 